\author{
Brigita Žuromskaitè \\ ORCID 0000-0002-6837-344X \\ Uniwersytet Michała Romera w Wilnie \\ Wydział Zarządzania Publicznego \\ Instytut Zarządzania \\ brigitaz@mruni.eu \\ Rafal Nagaj \\ ORCID 0000-0002-9410-7663 \\ Uniwersytet Szczeciński \\ Wydział Nauk Ekonomicznych i Zarządzania \\ Instytut Ekonomii \\ rafal.nagaj@usz.edu.pl
}

\title{
CULTURAL TOURISM FACILITIES IN THE CONTEXT OF THE INCREASED RISK OF TERRORISM: YOUNG TOURISTS FROM LITHUANIA AND SECURITY MEASURES
}

\begin{abstract}
In view of the events that have been taking place in recent years, tourism security issues have become a popular subject in academic research. Terrorism attacks in trendy tourism destinations have raised a significant question: how can the tourist be protected and provided with quality? The article presents an evaluation of the significance of 'soft' and 'hard' security measures used in cultural tourism facilities by young tourists from Lithuania. The research showed that young tourists belong to the group of 'courageous' travellers, but their bravery has a limit. Young people want to travel 'without restrictions', feeling free, but they also want to know that someone has taken care of their safety.
\end{abstract}

Keywords: tourist infrastructure, risk of terrorism, tourists' security.

\section{INTRODUCTION}

The terrorism attacks in September 2001 had a strong impact on the perception of security in tourism and of tourists' safety (TARLOV 2014). According to S.S. HORNER and J. SWARBROOKE (2009), in the $21^{\text {st }}$ century, it is tourists who often become a main terrorism target. This is due to the fact that they are easily recognizable (they look and behave differently) and are exposed to all kinds of terrorism attacks or states of emergency. In P.P. TARLOV'S (2006) opinion, the tourism sector should adapt to the new situation, be prepared for this kind of challenge and protect tourists against potential dangers, using all available resources.

The space where tourists may confront terrorism attacks is the tourism infrastructure, including accommodation and gastronomic facilities, as well as popular tourism attractions. As the literature on the subject shows, they are increasingly taking place in popular tourism destinations (mainly in tourism infrastructure facilities, such as hotels, restaurants, railway stations, cultural tourism facilities), visited by large numbers of tourists from all over the world (PACZYŃSKA-JĘDRYCKA \& EIDER 2017).
The question that arises is how can we protect tourists from a potential danger without reducing their comfort or constraining their personal space? The author of this article attempts to answer this research problem. The aim of the paper is to identify the security measures used in cultural tourism infrastructure and to present their significance in the opinions of young people from Lithuania. The methods used were a critical literature analysis and an analysis of the results of a survey conducted among young Lithuanians. The research subjects are young tourists, i.e. people born after 1980 who are willing to spend time and money on travelling (MOISĂ 2010). As shown by the literature review, they tend to choose new tourism destinations and travel for longer (How Millennials killed travel). Moreover, they are more open to new experiences, traditions, culture and meeting new people, compared to former generations (BUFFA 2015, MORRISON et al. 2016). It should be stressed, however, that young tourists are at the same time less cautious than the former, they are happy to share information, sometimes personal, on various websites and social 
networks (BARTON et al. 2013). They are also different from older people, who usually abandon a journey if there is any kind of danger at the destination (GARG 2015). The young are not so ready to do this (MACHADO 2014). However, according to P.P. MURA (2010), some of them are 'brave' only to a certain point. These facts make young tourists' opinions about the security measures used in the cultural tourism infrastructure important, and it may provide valuable academic information. As these problems have not been discussed with regard to this particular research group from Lithuania, in the context of new dangers faced by the global tourism sector, this article may contribute to research on the subject.

\section{TERRORISM VS TOURISM}

A necessary condition for tourism to develop in a region is a good political and economic situation (MANSFER $\&$, PIZAM 2006). An equally important factor is the level of tourists' security, i.e. the protection of their lives, health and property (BERNAŚ \& PUJER 2014), as it influences the way the tourism sector and destinations are perceived by tourists. It is worth pointing out that in recent years, tourists have changed their opinions about the importance of security levels while travelling. Consequently, some of them choose safe tourism regions, i.e. those where the tourism infrastructure provides a whole range of security measures and the death rate among tourists is low (SURVILA, MIKĖNAS \& ŽUROMSKAITE 2016). The results of the research presented in the literature (HORNER \&, SWARBROOKE 2009) show that terrorism attacks in tourism regions decrease the number of visitors. The negative impact of the terrorism threat on the tourism sector was confirmed by empirical studies conducted in 2016 and 2017 by International SOS and Ipsos Mori (Travel risk... 2016). In $2016,80 \%$ of the respondents said that they had had to change their plans and $51 \%$ claimed that the main reason was the terrorism threat (Travel risk... 2016, p. 1).

As shown by the research, terrorism attacks and threats directly affect tourism (ŽUROMSKAITĖ, NAGAJ \& DAČIULYTĖ 2018). The more such threats occur in a given area, the more probable it becomes that it will lose popularity among tourists, which will reduce the revenue gained from this sector.

A terrorism threat may have a negative influence on the development of the tourism sector on the local, regional and international scale (SANTANA 2005). It can be assumed, then, that tourists are sensitive to the security level and in high risk situations, they will give up travelling to such dangerous destinations.
Terrorism attacks carried out in popular tourism destinations raise huge interest in the global press. The media are not only a source of information about current events, but also shape tourists' knowledge about tourism regions. Due to the information appearing in the media, when tourists choose a potential destination, they have already formed an opinion and have a basic knowledge about the security level in a given tourism region (SCHROEDER et al. 2013). It is worth remembering, however, that the media sometimes stir additional emotions and unnecessarily instil fear among tourists. They do this by providing information which has not been verified, full of rumour and half-truths. In this way, they give rise to negative opinions about a given tourism destination as a dangerous place, while in fact the situation may be quite different.

The media are obviously not the only source of information concerning the risk level in tourism destinations. They may also be found on government websites or provided by tourism experts and travel agencies' employees. Equally important is the opinion of friends and family (ŽUROMSKAITE், NAGAJ \& DAČIULYTĖ 2018).

When analyzing the relationships between terrorism and tourism, we may notice that tourists are often affected by anchoring bias, and (with regard to specific geographical regions) the generalization effect, which occurs when the events in a given tourism destination are automatically generalized for the whole region, in the form of a negative opinion, despite the fact that in other destinations, threats of this type may not occur at all or are present on a much smaller scale. This is caused by subjective and objective factors. The former include susceptibility to cognitive distortions and excessive emotions, while the latter result from the fact that it is 'relatively easy' to make tourists the target of a terrorism attack. They are easy to track down (they spend most of their time in the tourism infrastructure) and identify (they wear different clothes, as well as look and behave differently) (MARCZAK 2012). Another important factor is the fact that the victims of terrorism attacks are often of various nationalities, which raises more interest on the part of the media in many countries and in this way enables the terrorisms to achieve their aim, which is publicizing their activity.

A measurable, negative effect of the growing threat of terrorism attacks in tourism destinations is a weakening of interest in visiting such places and the decreasing number of tourists choosing to travel there. This is automatically reflected in smaller revenues from tourism and the resulting negative economic consequences, such as failing businesses and growing unemployment in the tourism sector, and - nationally - a slower rate of Gross National Product (GNP) growth. 


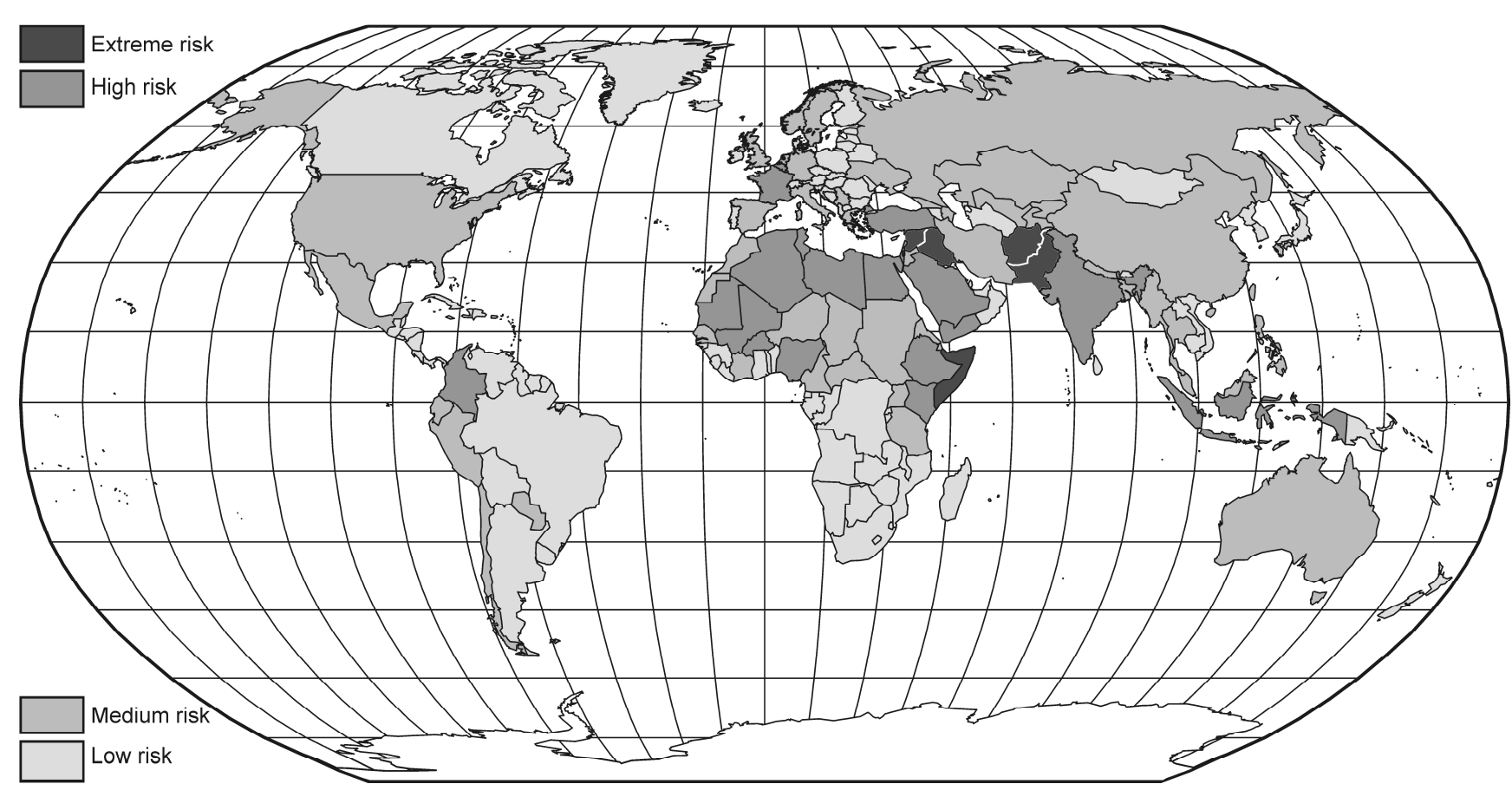

Fig. 1. Global Terrorism Risk Map

Source: red24's Global Terrorism Risk Map 2017

Fig. 1 presents terrorism threat levels around the world. Red and black indicate regions representing a high or very high risk of terrorism attacks. The data shows that the highest risk occurs in hotter regions, i.e. in North Africa, the Middle East, South Asia and Oceania. They are usually popular tourism regions or areas chosen as potential tourism destinations. Lithuania, whose young tourists are analysed in this article, is a country where the risk level is low. It may be the reason why these tourists may misjudge the security level and the potential threats in the destinations they visit.

\section{ECONOMIC EFFECTS OF TERRORISM ATTACKS IN THE TOURISM SECTOR}

Terrorism attacks affect not only the tourists' readiness to travel and the way they perceive a given tourism destination or region, but the economic situation of the tourism sector. An example of such an effect are the events of 11 th September 2001 (Horner \& Swarbrooke 2009), which brought substantial economic losses to airlines, accommodation and gastronomic facilities, as well as other enterprises cooperating with the tourism sector in the United States. What is interesting, despite the fact that the target of that attack was not tourists, it was exactly this sector that suffered the greatest economic losses. In the first month after the attack, the revenues of the tourism sector in the USA decreased by $33 \%$, the airlines lost about $50 \%$ of passengers, about $25 \%$ of conferences and other prestigious meetings were cancelled, and tourism enterprises lost 51 million USD in just one day (HORNER \& SWARBROOKE 2009). Moreover, the economy of the United States lost 1.8\% GNP, and 1.1 million people lost their jobs. As a result of generalization, the economic effect concerned not only the sites of the terrorism attacks, but also the regions associated with the United States. A good example are the Caribbean islands, which were visited by $13.5 \%$ fewer tourists at that time, and where about 365,000 employees were made redundant. Great Britain - a strategic partner - lost 16 million GBP in three months (HORNER \& SWARBROOKE 2009, pp. 360-361). According to other authors, representatives of tourism infrastructure react to tourists' changing behaviour and take action in order to reduce the potential risk and protect the tourists, as well as minimize the decrease in comfort (SURVILA, MIKĖNAS \& ŽUROMSKAITE் 2016). The security measures that started to be commonly used in accommodation facilities include visitors' baggage screening, inspecting the vehicles arriving at the facility, installing metal detectors at entrances, fitting bullet-proof window panes, monitoring systems/cameras and armed security guards on duty for 24 hours (HENDERSON 2007, pp. 6364). The security measures introduced in cultural tourism facilities include additional cameras, tourism police, metal detectors at entrances, as well as 
checking tourists' personal belongings at entrances. All these precautions produce costs, which the tourism sector had to and still has to incur in order to raise the security level.

These are, of course, not the only actual or potential actions taken by representatives of the tourism sector and cooperating enterprises with regard to the growing terrorism threat which have economic effects (the effects of reducing revenues, employment and investment in the tourism sector) (HORNER \& SWARBROOKE 2009, SANTANA 2005). For instance, airlines may stop using large planes and replace them with smaller ones, or reduce the number of onboard staff to dangerous tourism destinations. Travel agencies may withhold selling trips to dangerous tourism regions or their individual parts.

It is difficult to even estimate all the economic effects of the increased terrorism threat. However, according to P.P. TARLOV (2006), tourists' safety should be the priority for everybody working in the tourism sector. You can, of course, argue with this statement, because the question is whether all the security measures will bring the expected effect and will not have a negative influence on the quality of recreation in a given tourism region.

\section{THE COURSE OF THE RESEARCH AND A DESCRIPTION OF RESPONDENTS}

The aim of this article is to identify the security measures used in the cultural tourism infrastructure and present an evaluation of their significance by young tourists from Lithuania. This objective as achieved by conducting a critical analysis of the literature on the subject and a diagnostic survey. The literature review served the purpose of identifying the security measures, which were then evaluated by the respondents and underwent an empirical analysis by the authors. In the survey, the respondents evaluated the security measures listed by J.C. HENDERSON (2007) and by the authors of this article who referred to their own observations at popular cultural tourism facilities. In order to examine the opinions of young tourists from Lithuania about the security measures used in the cultural tourism infrastructure as well as their significance, a questionnaire survey was conducted over the period of January-May 2018. Using the Likert scale (from 1 - insignificant to 5 - very important), the respondents rated the main security measures used in the cultural tourism infrastructure. They had to evaluate the following: military patrols, additional cameras, medical emergency teams on duty at the facility, tourism police, metal detectors at the entrances to the facilities, checking tourists' personal belongings at entrances, verifying documents, putting fences around tourism facilities, employing security guards, distributing leaflets about potential threats and information about existing risks.

The survey included 358 young tourists from Lithuania (the research was carried out at the Mykolas Romeris University in Vilnius). The majority of respondents were aged $20-29,47 \%$ of whom were $20-24$, and $29 \%$ were $25-29$ years of age. The remaining respondents were younger or older. The majority (76.5\%) were women and $23.5 \%$ were men. $70 \%$ were in a permanent relationship, $78 \%$ did not have children. As regards employment, $71 \%$ were working and $29 \%$ were students. The research included only those who went on a tourist trip at least once a year. Most respondents travelled frequently: 42\% - 2-3 times, $13 \%-4-7$ times, and $5.3 \%-8$ or more times a year. Only $28 \%$ travelled only once a year. The sample group of tourists from Lithuania usually travel for cognitive purposes (21.7\%) and recreation (24.7\%) (Fig. 2).

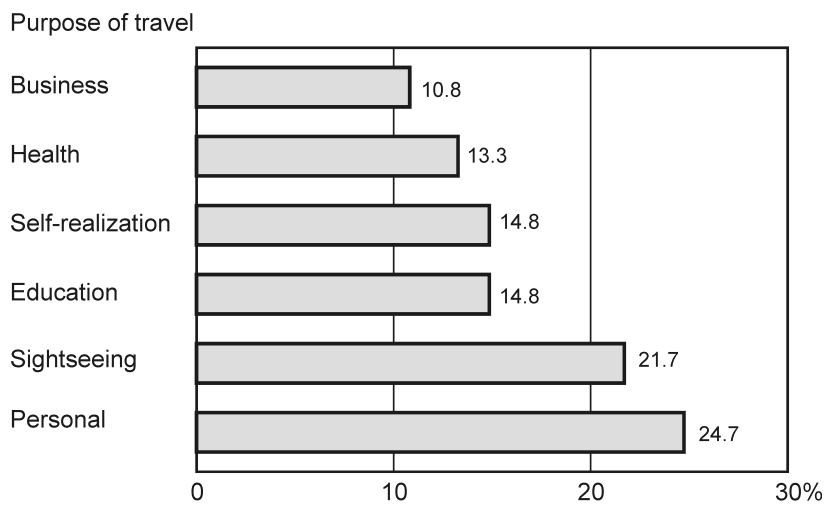

Fig. 2. Purpose of travel of young tourists from Lithuania Source: authors

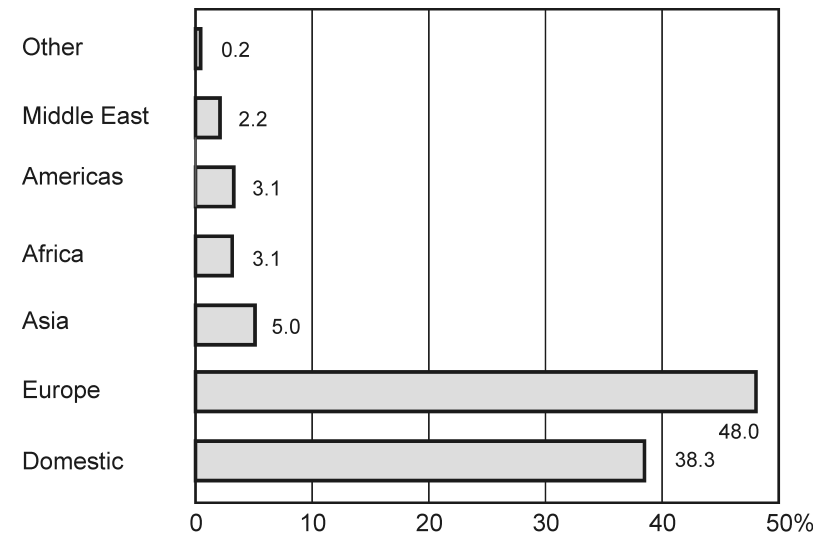

Fig. 3. The main travel destinations of young tourists from Lithuania Source: authors

Analysis of travel destinations showed that the young tourists most frequently chose Europe (48\%) and their own country $(38.3 \%)$. Only a small propor- 
tion (ca. 5.5\%) visit tourism regions with a higher risk factor or considered travelling to dangerous places (see Fig. 3), or places which are advised against as travel destinations by the country's authorities. However, a substantial proportion of the respondents travel to West European countries, despite the fact that some of them are places considered to be at a higher terrorism risk.

The respondents were also grouped according to the average level of expenses paid for the trip (Fig. 4). The results of the survey show that young tourists in Lithuania usually spend over 200 Euro for their trip (34.1\% - 401-800 EUR, and 29.6\% - 201-400 EUR).

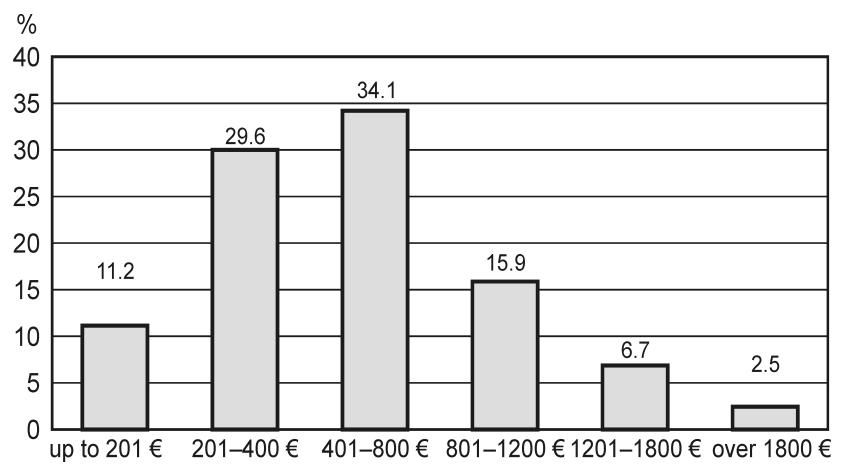

Fig. 4 . The amount of money spent on the trip by young tourists from Lithuania Source: authors

The young inhabitants of Lithuania included in the study do not spend large sums on tourist trips, which means that they are interested in going on a journey and see as much as possibly, rather than investing in the standard of the trip, i.e. in the tourism infrastructure (they choose cheap flights and lower standards of accommodation).

\section{SECURITY MEASURES IN CULTURAL TOURISM INFRASTRUCTURE}

As indicated in the objective of the article, the research objective was an evaluation of the main security measures used in the cultural tourism infrastructure. The results show that the respondents evaluate all the security measures found in tourism facilities in a similar way, i.e. at least half of the respondents considered almost all of them to be important and needed or very important and indispensable (Fig. 5).

The security measure used in cultural tourism infrastructure which most $(72.3 \%)$ young tourists pointed to are additional cameras. Three other measures were also rated highly or very highly by nearly two thirds of respondents: fencing tourism facility premises and employing security guards $(61.5 \%)$, checking tourists' personal belongings at entrances $(61.2 \%)$ and tourism police $(61.2 \%)$. These are 'soft' security measures which are not even noticed by the majority of tourists while visiting cultural tourism facilities (e.g. cameras).

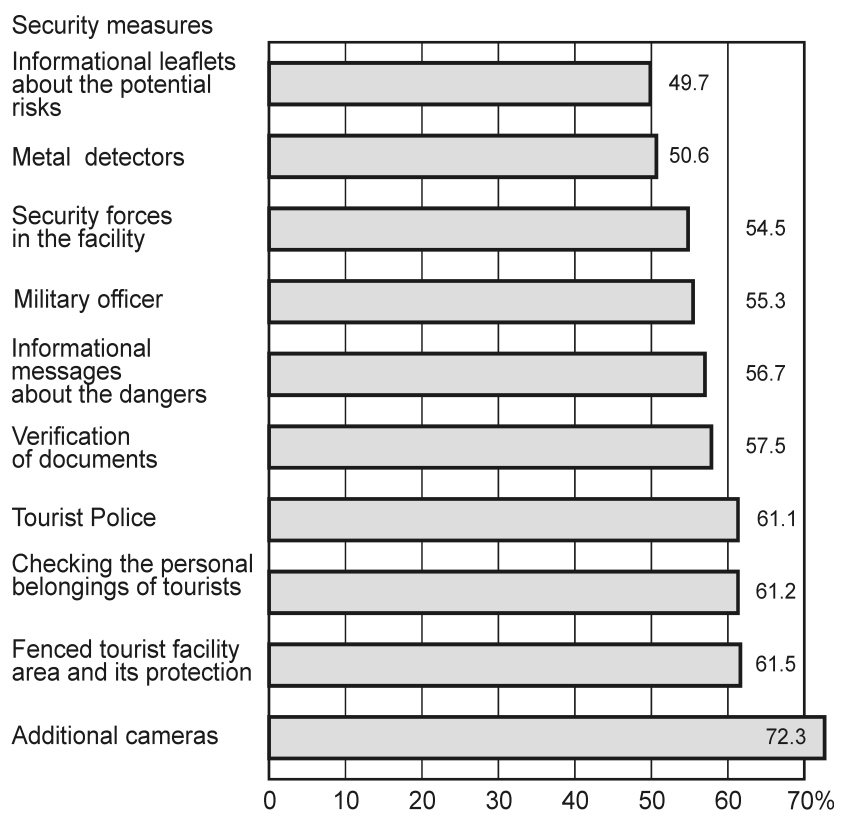

Fig. 5. Security measures in tourism facilities that are important or very important for the respondents

Security measures

Additional cameras

Tourist Police

Fenced tourist facility area and its protection

Checking the personal belongings of tourists

Security forces in the facility

Metal detectors

Military officer

Verification of documents Informational messages about the dangers Informational leaflets about the potential risks

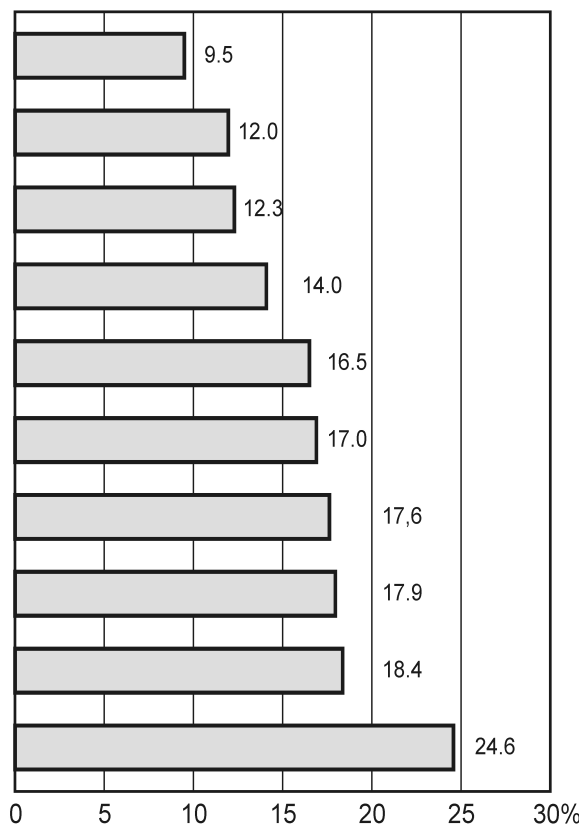

Fig. 6. Security measures in tourism facilities which lower the quality of the trip of young tourists from Lithuania Source: authors

The majority of young Lithuanian tourists did not indicate any of the security measures as not needed (Fig. 6). The respondents said that the security measures which would most disturb visiting tourism 
facilities, are leaflets informing about potential risks $(24.6 \%)$ and news about the threats $(18.4 \%)$. This is interesting, because the most 'disturbing' security precautions do not include any 'hard' measures, which may indicate that the respondents are aware of the threats though they do not like being informed about them.

\section{CONCLUSION}

Based on the literature review and the empirical studies that were conducted, it was possible to formulate the following conclusions:

1. In times of an increased risk of terrorism attacks, tourists must be protected and kept safe, especially that the attacks more and more often take place at cultural tourism facilities. Tourists are more or less aware of the threat, but they do not want to stop travelling and they expect to be protected from this type of danger.

2. The new challenge faced by the tourism sector, the protection of tourists and tourist infrastructure against terrorism attacks, requires introducing certain security measures. It is problematic, however, how 'soft' and 'hard' security measures are to be used so that tourists are not discouraged from visiting some tourism regions or the standard of tourism facilities does not worsen.

3. If security measures against terrorism attacks are not introduced, tourism regions are threatened with serious economic consequences, such as drastically falling incomes, rising unemployment, reduced employment in the tourism and transport sectors, losses in enterprises cooperating with them, or lack of investments in tourism infrastructure, etc.

4. The survey conducted among young Lithuanian tourists showed that they travel quite often, but they usually choose Europe as their destination and do not have contact with regions in danger of terrorism attacks. Economically they are those tourists who tend to choose budget accommodation and cheap airlines.

5. Although young Lithuanian tourists are more ready for adventure while travelling, it does not mean that they remain unconcerned about the threat of terrorism attacks or that they do not care about their own safety. The study indicates that they have a positive attitude towards the security measures used in cultural tourism infrastructure and consider them to be an element which improves the quality of their recreation.
6. Young Lithuanian travellers follow the trend observed in other countries (and presented in the literature) they are inclined to take risks and disregard security issues. The respondents opt for 'soft' security measures rather than 'hard' to be used at tourism facilities/attractions.

\section{BIBLIOGRAPHY}

BARTON C., HAYWOOD J., JHUNJHUNWALA P., BHATIA V., 2013, Travelling with Millennials. The Boston Consulting Group, http://www.bcg.com/documents/file129974.pdf.

BERNAŚ B., PUJER K., 2014, Bezpieczeństwo i zagrożenia w turystyce, The Wroclaw School of Banking Research Journal, 15, 2, pp. 223-243.

BUFFA F., 2015, Young tourists and sustainability. Profiles, attitudes, and implications for destination strategies, Sustain-ability, 7, s. $14042-14062$.

GARG A., 2015, Travel risks vs tourist decision making: A tourist perspective, International Journal of Hospitality $\mathcal{E}$ Tourism Systems, 8 (1), pp. 1-9.

HENDERSON J.C., 2007, Tourism crises: causes, consequences and management, Elsevier, Amsterdam.

HORNER S., SWARBROOKE J., 2009, International cases in tourism management, Elsevier, Amsterdam.

How Millennials killed travel marketing as we know it, http:/ / www. mdgadvertising.com/e-books/How-Millennials-Killed-TravelMarketing/Millennial-Traveler-Ebook.pdf.

MACHADO A., 2014, How Millennials are changing travel, https:/ / www.theatlantic.com/international/archive/2014/06/howmillennials-are-changing-international-travel/373007/.

MANSFELD Y., PIZAM A., 2006, Tourism, security and safety: from theory to practice, Elsevier, Amsterdam.

MARCZAK M., 2012, Wpływ terroryzmu na rozwój turystyki międzynarodowej, Zeszyty Naukowe Uniwersytetu Szczecińskiego. Ekonomiczne Problemy Turystyki, 4, 20, pp. 89-102.

MOISĂ C.O., 2010, Aspects of the youth travel demand, Annales Universitatis Apulensis Series Oeconomica, 12 (2), pp. 575-582.

MORrison G., Fernandes L., HAyASHI C., 2016, Millennial traveller report. Factory \& expedia, https://www.foresight factory. co/wp-content/uploads/2016/11/Expedia-MillennialTravel ler-Report-Final.pdf.

MURA P., 2010, 'Scary... but i like it!' Young tourists' perceptions of fear on holiday, Journal of Tourism and Cultural Change, 8 (1-2), pp. 30-49.

PACZYŃSKA-JĘDRYCKA M., EIDER J., 2017, Turystyka w obliczu terroryzmu, Handel Wewnętrzny, 4 (369), pp. 196-205.

red24's Global terrorism risk map 2017, https://opinion.red24. com/2017/01/10/red24s-global-terrorism-risk-map-2017/.

SANTANA G., 2005, Globalisation, safety and national security, [in:] W. Salah, C. Cooper (eds.), Tourism in the age of globalisation, Routledge, London, New York, pp. 213-241.

SCHROEDER A., PENNINGTON-GRAY L., KAPLANIDOU K., ZHAN F., 2013, Destination risk perceptions among US residents for London as the Host City of the 2012 Summer Olympic Games, Tourism Management, 38, pp. 107-119.

SURVILA A., MIKĖNAS E., ŽUROMSKAITĖ B., 2017, The impact of terrorism on the tourism sector of Lithuania, Montenegrin Journal of Economics, 13, 3, pp. 101-118. 


\section{Articles}

TARLOW P., 2006, A social theory of terrorism and tourism, [in:] Y. Mansfeld, A. Pizam (eds.), Tourism, security and safety: from theory to practice, Elsevier, Amsterdam, pp. 33-48.

TARLOW P., 2014, Reflective epilogue: concerns in tourism safety, International Journal of Religious Tourism and Pilgrimage, 2, pp. 68-70.

Travel risk and reality. The new normal for business 2016; https:// www.internationalsos.com/risk-outlook.
ŽUROMSKAITĖ B., NAGAJ R., DAČIULYTĖ R., 2018, Source of information on the perceived risk and safety in the tourism Industry, [in:] N. Grünwald, M. Zakrzewska (eds.), Series of the Robert-Schmidt-Institut: Proceedings of the $5^{\text {th }}$ International Scientific Conference on "Modern Economics", University of Wismar, Wismar, pp. 179-185.
Article received 27 August 2018 Accepted:

4 November 2018 